\title{
Pengaruh Akreditasi Rumah Sakit dalam Perubahan Tingkat Kepatuhan Pengisian Surgical Safety Checklist di RS Nur Hidayah
}

\author{
Annisa Firdausi ${ }^{1}$, Arlina Dewi ${ }^{2}$, Susanto $^{3}$ \\ ${ }^{1,2,3}$ Program Studi Manajemen Rumah Sakit, Universitas Muhammadiyah Yogyakarta \\ Jalan Lingkar Selatan, Tamantirto, Kasihan, Bantul, Yogyakarta $55183^{123}$ \\ Correspondence e-mail: nisafirdausi@gmail.com
}

\begin{abstract}
Abstrak. Komplikasi dan kematian akibat tindakan pembedahan menjadi salah satu masalah kesehatan global. WHO memperkirakan sedikitnya terdapat kurang lebih setengah juta kematian akibat tindakan pembedahan yang sebenarnya dapat dicegah. WHO meluncurkan sebuah kampanye pada tahun 2008 bertema "Safe Surgery Saves Lives" dan mengeluarkan sebuah checklist yaitu Surgical Safety Checklist (SSC) yang didesain untuk mengurangi angka komplikasi dan kematian yang berhubungan dengan tindakan pembedahan. Pelaksanaan kegiatan akreditasi bermanfaat untuk meningkatkan mutu pelayanan rumah sakit atau penyedia jasa kesehatan lainnya, sejak pengggunaan instrumen standar akreditasi rumah sakit versi 2012, terdapat perubahan yang cukup bermakna yaitu perubahan standar yang semula berfokus kepada pemberi pelayanan, diarahkan menjadi berfokus kepada keselamatan pasien. Dengan adanya kegiatan akreditasi diharapkan adanya perubahan dalam tingkat kepatuhan pengisian SSC untuk meningkatkan angka keselamatan pasien. Untuk mengetahui pengaruh akreditasi rumah sakit dalam perubahan tingkat kepatuhan pengisian surgical safety checklist di RS Nur Hidayah. Penelitian ini merupakan penelitian kuantitatif deskriptif dengan pengambilan data melalu telaah dokumen. Sampel yang diambil sebanyak 75 SSC sejak bulan Juni 2017, Agustus 2017, Januari 2018, Juli 2018, dan Januari 2019. Analisis data ditampilkan dalam bentuk table statistik dan prosentase. Kelengkapan surgical safety checklist di RS Nur Hidayah pada seluruh item rata - rata mengalami perubahan pada tingkat kepatuhan. Tingkat kepatuhan tertinggi ditemukan pada saat menjelang akreditasi dan sebulan setelah akreditasi. Item sign in merupakan item yang terisi paling lengkap dengan rata - rata tingkat kepatuhan sebanyak 95.6\%, sedangkan item sign out merupakan item yang didapatkan paling rendah tingkat kepatuhannya dengan rata - rata sebanyak $74.8 \%$.
\end{abstract}

Kata kunci: akreditasi; kepatuhan; surgical safety checklist

Abstract. Death and complication due to surgeries or surgical actions is a global health problem. The WHO estimates that at least half a million deaths that are caused by surgeries can be prevented. On 2008, the WHO released a campaign about safe surgery and the surgical safety checklist to improve the quality of our surgery cases and decrease the number of complication and deaths caused by surgeries. Hospital accreditation is used to improve the quality of hospital management, including in reducing numbers of death and complication due to surgeries. This is a quantitative descriptive approach study. The study population used were all surgical safety checklist. Sample number of 75 surgical safety checklist, 15 surgical safety checklist each from June 2017, August 2017, January 2018, June 2018, and January 2019. Data analysis shown by statistic table and percentage. There was a change of number in completing compliance of the surgical safety checklist before and after hospital accreditation. It showed that nearing hospital accreditation, the compliance rate was almost $100 \%$ on all the items. This continued a month after, but some of the items had a lower rate of compliance further after the hospital accreditation. The number of completing compliance of the surgical safety checklist nearing hospital accreditation is higher than after hospital accreditation. The sign in item have the highest rate of completing compliance whereas the sign out item had the lowest number of compliance.

Keywords: accreditation; compliance; surgical safety checklist

\section{PENDAHULUAN}

Kamar bedah merupakan suatu unit yang memberikan proses pelayanan pembedahan yang banyak mengandung risiko. Angka terjadinya kasus kecelakaan di kamar bedah operasi sangat tinggi, jika dalam pelaksanaanya tidak memperhatikan pasien, kesiapan pasien, dan prosedur tindakan. Diperkirakan bahwa sekitar 234 juta tindakan pembedahan mayor dilakukan setiap tahunnya di seluruh dunia. Dikarenakan adanya peningkatan dari pentingnya tindakan pembedahan secara global di dunia medis, keselamatan pasien dan kualitas dalam tindakan pembedahan mendapatkan perhatian yang lebih (Haugen et al, 2013).

Komplikasi dan kematian akibat tindakan pembedahan menjadi salah satu masalah kesehatan global. WHO memperkirakan sedikitnya terdapat kurang lebih setengah juta kematian akibat tindakan pembedahan yang sebenarnya dapat dicegah (Weiser et al, 2008). Di Inggris dan Wales, National Patient Safety Agency melaporkan adanya 127.419 insiden terkait pembedahan pada tahun 2007.

Sampai saat ini di Indonesia belum ada data yang lengkap tentang angka kematian dan komplikasi pembedahan, maupun data lengkap tentang praktik keselamatan pasien (patient safety) pada tindakan pembedahan. Keselamatan pasien sebagai sebuah sistem diharapkan akan dapat memberikan asuhan yang lebih aman untuk pasien dengan mencegah terjadinya cidera akibat kesalahan karena melakukan tindakan atau tidak melakukan tindakan yang seharusnya dilakukan. Dalam 
Annisa Firdausi et al, Pengaruh Akreditasi Rumah Sakit dalam Perubahan Tingkat Kepatuhan Pengisian Surgical Safety Checklist di RS Nur Hidayah

pelaksanaanya, keselamatan pasien akan banyak menggunakan prinsip dan metode manajemen risiko mulai dari identifikasi, assessment dan pengelolaan risiko (Departemen Kesehatan, 2009).

Budaya keselamatan pasien disusun oleh berbagai dimensi, yaitu kerja tim, kepemimpinan, beban kerja, komunikasi, dan sistem keamanan (NHS, 2010). Dengan adanya budaya keselamatan pasien, diharapkan kasus medical error dapat diminimalisir. Hal ini dikarenakan budaya keselamatan adalah kunci pokok dalam mencapai kenaikan angka penerapan keselamatan kerja dan kesehatan kerja dalam suatu organisasi (KKP-RS, 2007). Dengan demikian faktor kepegawaian, kepemimpinan dan manajemen, lingkungan fisik dan akreditasi rumah sakit, dan juga kriteria perawat pelaksana dapat mempengaruhi penerapan sistem budaya keselamatan pasien (Jardali el at, 2011). Dari banyak faktor tersebut, pada penelitian ini yang akan menjadi fokus penelitian adalah faktor akreditasi rumah sakit.

Akreditasi merupakan pengakuan oleh publik yang dilakukan oleh instansi akreditasi pada bagian pelayanan kesehatan nasional dalam suatu instansi pelayanan kesehatan pada tingkat pencapaian terhadap tingkat kinerja yang terkait dengan standar yang ada dalam proses tercapainya standar akreditasi yang kemudian diwujudkan melalui penilaian eksternal oleh peer secara mandiri. Jardali et al (2011) menyebutkan bahwa fasilitas kesehatan yang terakreditasi mempunyai staf dengan frekuensi dan persepsi terhadap pelaporan terkait insiden keselamatan pasien yang lebih tinggi daripada fasilitas kesehatan yang tidak terakreditasi.

Menurut Sutoto (2013) sejak pengggunaan instrumen standar akreditasi rumah sakit versi 2012, terdapat perubahan yang cukup bermakna yaitu perubahan standar yang semula berfokus kepada pemberi pelayanan, diarahkan menjadi berfokus kepada keselamatan pasien.

Berdasarkan latar belakang yang telah diuraikan di atas, peneliti tertarik untuk melakukan penelitian dengan judul "Pengaruh Akreditasi Rumah Sakit Dalam Perubahan Tingkat Kepatuhan Pengisian Surgical Safety Checklist di RS Nur Hidayah."

\section{METODE}

Penelitian ini merupakan penelitian deskriptif dengan pendekatan kuantitatif. Pada desain penelitian deskriptif ini, peneliti tidak melakukan perlakuan atau intervensi apapun terhadap variable penelitian. Data yang didapat berupa data yang sudah ada sebelumnya maupun data yang dibuat kemudian tanpa campur tangan peneliti (Jasaputra et al, 2008).

Penelitian ini meneliti tentang kelengkapan pengisian surgery safety checklist yang dikeluarkan oleh WHO dan standar akreditasi rumah sakit. Subyek yang digunakan pada penelitian ini adalah surgical safety checklist di RS Nur Hidayah pada bulan Juni tahun 2017, Agustus tahun 2017, Januari tahun 2018, Juli tahun 2018, dan Januari 2019. Sebanyak 75 SSC digunakan sebagai sampel dari populasi seluruh SSC yang ada di RS Nur Hidayah. Rekapan data yang diperoleh dari rekam medis disajikan dalam bentuk tabel kemudian dideskripsikan dalam bentuk naratif.

\section{HASIL DAN PEMBAHASAN}

\section{Tren Kepatuhan Pengisian Checklist untuk Data Identitas}

Secara umum kepatuhan pada pengisian data identitas belum mencapai maksimal, dan prosentase kepatuhan naik turun dari waktu ke waktu. Hal tersebut dapat dilihat pada gambar 1. Rerata prosentase kepatuhan cenderung meningkat pada bulan Januari tahun 2018 dan 2019, serta menurun pada tiga masa penelahaan lainnya (Juni, Juli dan Agustus). Ini sangat disayangkan, karena meskipun poin identitas pada surgical safety checklist maupun rekam medis terkesan sepele dan tidak terlalu diperhatikan namun masih banyak tenaga kesehatan yang tidak melengkapinya dengan baik. Padahal bagian identitas merupakan hal yang sangat krusial. Temuan ini sesuai dengan hasil penelitian yang dilakukan oleh Ridho et al (2013), yaitu bahwa aspek kelengkapan rekam medis yang sering tidak lengkap adalah bagian nama dan tanda tangan dokter sebanyak 23,35\%, koreksi kesalahan sebanyak $16,21 \%$, identitas pasien sebanyak 3,85\% dan tanggal dan waktu yaitu sebesar $1,65 \%$.

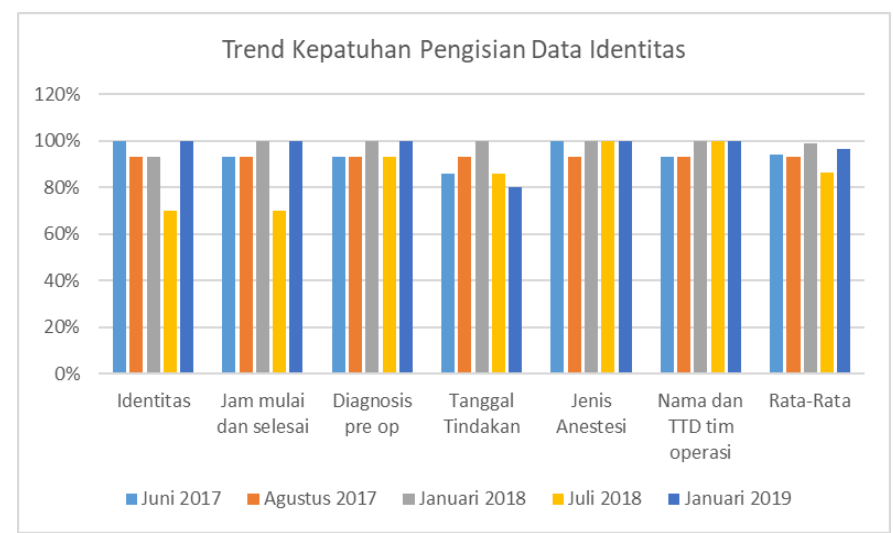

Gambar 1. Tren Kepatuhan Pengisian Data Identitas

\section{Tren Kepatuhan Pengisian Checklist untuk Item Fase Sign In}

Dapat dilihat pada gambar 2, tingkat kepatuhan pengisian checklist saat fase sign in secara umum juga belum mencapai maksimal, dan prosentase kepatuhan naik turun dari waktu ke waktu. Rerata prosentase kepatuhan cenderung meningkat pada bulan Januari dan Juli tahun 2018 serta Januari 2019. Kepatuhan terendah untuk fase sign in pada bulan Agustus 2017. Pada fase sign in, item yang paling sedikit tingkat kepatuhannya justru pada bagian sisi operasi yang ditandai (84.8\%). Konfirmasi identitas pasien dan pemberian tanda pada sisi operasi dapat mengurangi resiko kesalahan operasi 
Annisa Firdausi et al, Pengaruh Akreditasi Rumah Sakit dalam Perubahan Tingkat Kepatuhan Pengisian Surgical Safety Checklist di RS Nur Hidayah

pada orang ataupun sisi yang dioperasi (Panaser et al, 2011).

Beberapa faktor yang mempengaruhi kesalahan operasi dan atau salah sisi terletak pada tahapan sign in, seperti tidak dilakukannya konfirmasi identitas pasien, tidak dilakukannya penandaan sisi operasi yang berdampak pada operasi salah pasien dan operasi salah sisi, sehingga fase sign ini harus konsisten dijalankan (Blanco et al, 2007). Sedangkan untuk item yang paling lengkap pengisiannya adalah pada item konfirmasi identitas, konfirmasi jenis prosedur, dan pelaksanaan inform consent (100\%). Di sini menunjukkan bahwa kesadaran untuk preparasi pasien sebelum operasi sudah baik dan dianggap sebagai komponen yang penting untuk diperhatikan dan harus rutin dilakukan.

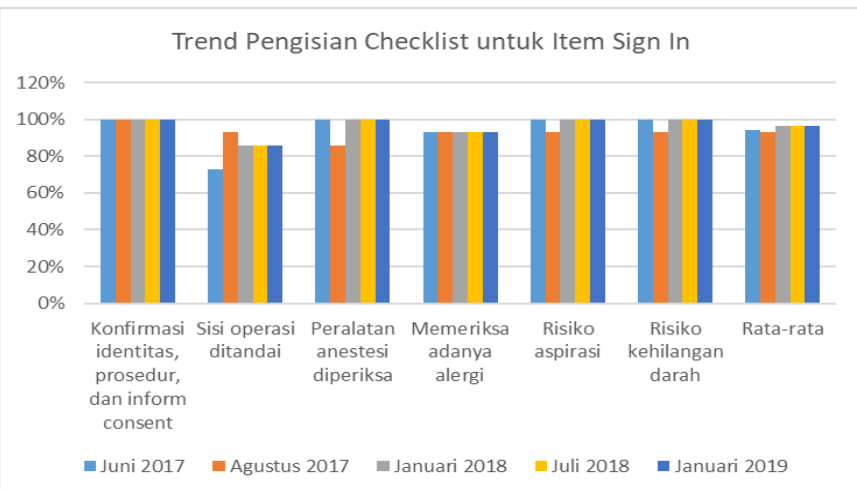

Gambar 2. Tren Kepatuhan Pengisian Checklist untuk Item Sign In

\section{Tren Kepatuhan Pengisian Checklist untuk Item Fase Time Out}

Untuk tingkat kepatuhan pengisian checklist pada fase time out yang dapat dilihat pada gambar 3 juga belum mencapai maksimal, kecuali pada bulan Juni 2017 yang telah mencapai $100 \%$, yaitu sebulan sebelum akreditasi. Rerata prosentase kepatuhan dari waktu ke waktu cenderung sama. Rerata kepatuhan terendah untuk fase time out juga terjadi pada bulan Agustus 2017 (93\%). Item yang paling rendah tingkat kepatuhan pengisiannya adalah pada pemberian antibiotik profilaksis 60 menit sebelum operasi. Pemberian antibiotik profilaksis sebelum operasi bertujuan untuk mencegah terjadinya infeksi pada luka operasi.

Menurut Weiser et al (2008), hampir 234 juta operasi yang dilakukan tiap tahunnya dan 1 juta orang dari opersi tersebut meninggal. Sedangkan 7 juta orang lainnya mengalami komplikasi salah satunya yaitu infeksi luka operasi. Untuk item yang paling tinggi angka kepatuhannya adalah item perkenalan diri dari semua anggota tim operasi serta konfirmasi nama pasien, prosedur, dan sisi operasi (98.6\%).

Tingkat kepatuhan pengisian item time out sempat menurun sebulan setelah akreditasi dilakukan, yaitu pada bulan Agustus 2017 dan Januari 2018. Namun kembali meningakat pada bulan Juli 2018 dan Januari 2019.

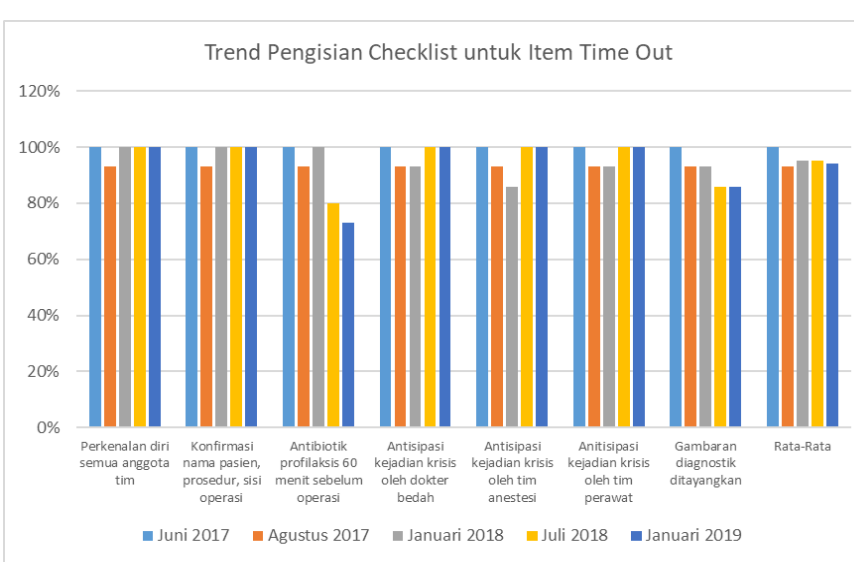

Gambar 3. Tren Kepatuhan Pengisian Checklist Pada Fase Time Out

\section{Tren Kepatuhan Pengisian Checklist untuk Item Fase Sign Out}

Secara umum tingkat kepatuhan pengisian checklist fase sign out juga belum mencapai maksimal, hal tersebut dapat dilihat pada gambar 4. Rerata prosentase kepatuhan dari waktu ke waktu cenderung menurun. Rerata kepatuhan pengisian checklist item pada fase sign out merupakan yang terendah jika dibandingkan dengan kepatuhan pengisian checklist pada item fase sign in dan time out. Hal tersebut serupa dengan hasil temuan penelitian yang dilakukan oleh Karlina (2018), di mana sebagian besar responden tidak patuh dalam mengisi item sign out. Rerata kepatuhan terendah sekitar $66 \%$ terjadi pada kurun waktu Januari 2019.

Vogts et al (2011) mengatakan bahwa item sign out hampir slelau diabaikan pada saat pengisian surgical safety checklit, sehingga dapat menimbulkan peningkatan risiko kelalaian dalam perawatan pasca operasi. Hal serupa ditemukan oleh Bashford et al (2014), di mana hasil penelitiannya menunjukkan bahwa bagian item sign out merupakan bagian yang tersulit untuk diselesaikan dari seluruh item surgical safety checklist. Hasil yang sama didapatkan oleh Prakoso (2018) dimana penelitiannya menunjukkan bahwa pada fase sign out hanya dilakukan sebanyak $85.6 \%$.

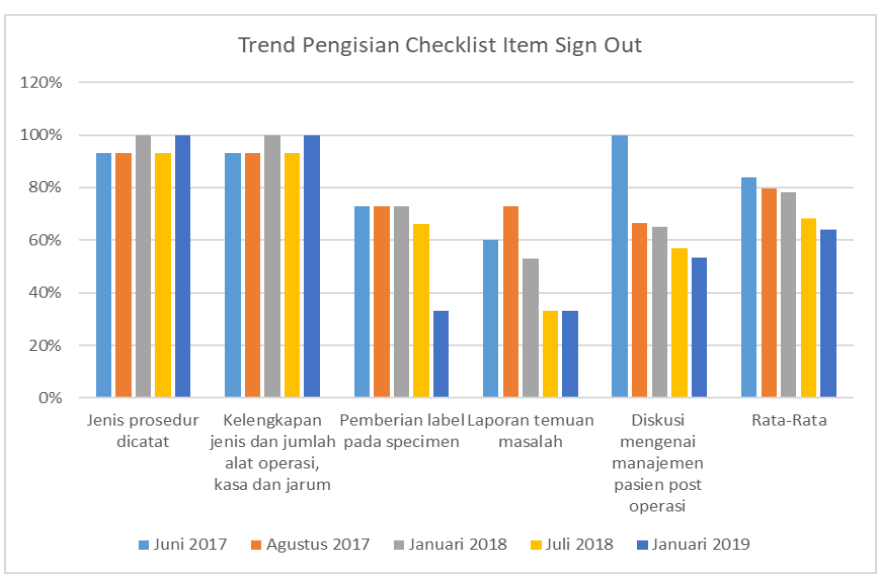

Gambar 4. Tren Kepatuhan Pengisian Checklist pada Fase Sign Out 
Annisa Firdausi et al, Pengaruh Akreditasi Rumah Sakit dalam Perubahan Tingkat Kepatuhan Pengisian Surgical Safety Checklist di RS Nur Hidayah

Trend Rerata Prosentase Kepatuhan Pengisian Checklist pada Tiap Fase

Dari grafik pada gambar 5, rerata prosentase tingkat kepatuhan pengisian surgical safety checklist cenderung stabil di kisaran $95 \%$ dari masa ke masa untuk fase sign in. Sedangkan untuk pengisian checklist pada fase time out data identitas cenderung naik turun meskipun kenaikan dan penuruanan tidak drastis. Yang perlu menjadi perhatian adalah rerata prosentase tingkat kepatuhan pengisian checklist untuk fase sign out. Terjadi penurunan secara konsisten dari masa ke masa mulai dari rerata 83\% pada bulan Juni 2017 menjadi hanya $63 \%$ pada Januari 2019. Perlu diteliti lebih lanjut apakah yang menajdi penyebab rendahnya tingkat kepatuhan pengisian surgical safety checklist untuk fase sign out.

Wangoo et al (2016) mengatakan bahwa secara keseluruhan tingkat inisiasi penggunaan surgical safety checklist cukup tinggi, namun untuk tingkat kepatuhan pengisiannya sendiri bervariasi dari $2 \%$ hingga $99 \%$. Dari sebagian besar penelitian, kepatuhan pengisian item sign out seringkali diabaikan. Namun terdapat perbedaan pada saat data penelitian dilakukan secara telusur dokumen dan observasi.

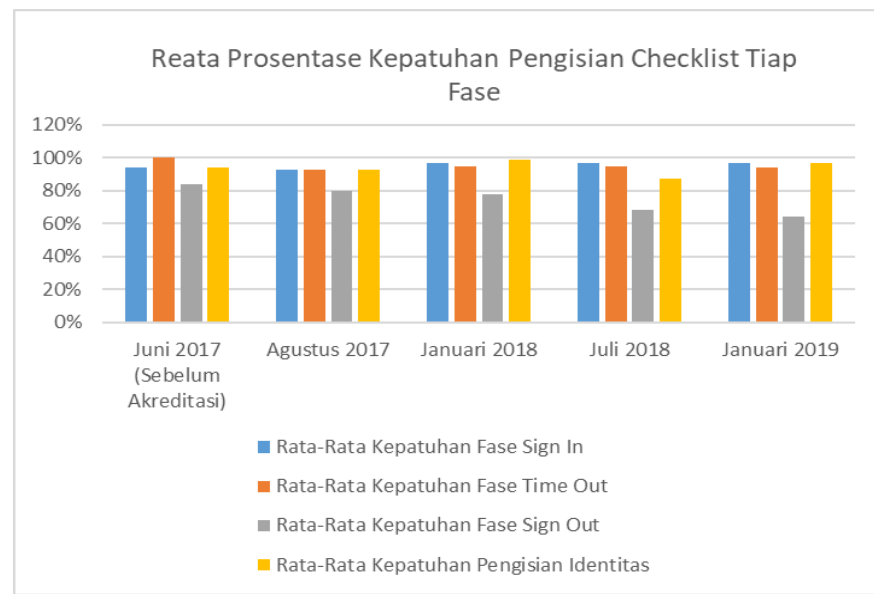

Gambar 5. Tren Rerata Prosentase Kepatuhan Pengisian Chcklist Pada Tiap Fase

\section{SIMPULAN}

Dari penelitian ini dapat disimpulkan bahwa pengisisan surgical safety checklist tidak patuh dengan prosentase kelengkapan surgical safety checklist tidak $100 \%$. Terdapat penurunan tingkat kelengkapan surgical safety checklist satu tahun setelah akreditasi. Pada item fase sign out didapatkan paling banyak poin yang tidak dilengkapi sedangkan pada item fase sign in didapatkan paling banyak poin yang dilengkapi. Terdapat perubahan pada tingkat kepatuhan pengisian surgical safety checklist sebelum dan sesudah akreditasi dilakukan.

\section{DAFTAR PUSTAKA}

Blanco, M., Clarke, JR., Martindell. 2009. Wrong site surgery near misses and actual occurrences. AORN J. pp 215-218.221-222.

Departemen Kesehatan Republik Indonesia. 2009. Buku Pedoman Nasional Keselamatan Pasien (Patient Safety) Rumah Sakit. Bakti Husada. Jakarta.

Haugen, A. S., et al. 2013. Impact of The World Health Organization's Surgical Safety Checklist On Safety Culture In The Operating Theatre: A Controlled Intervention Study. British Journal of Anaesthsia.

Jardali, F. E., et al. 2011. Predictors And Outcomes Of Patient Safety Culture In Hospitals. (Dapat diakses

https://bmchealthservres.biomedcentral.com/articl es/10.1186/1472-6963-11-45).

Jasaputra, D. K., Santosa, S. 2008. Metodologi Penelitian Biomedis. Edisi 2. Bandung: PT Danamartha Sejahtera Utama.

Karlina, S. 2018. Evaluasi Kepatuhan Tim Bedah Dalam Penerapan Surgical Safety Checklist WHO Pada Operasi Operasi Bedah Mayor Di Instalasi Bedah. Program Studi Magister Rumah Sakit. Universitas Muhammadiyah Yogyakarta. (Dapat diakses

http://repository.umy.ac.id/handle/123456789/228 24)

Komite Keselamatan Pasien Rumah Sakit. 2007.

Pedoman Pelaporan Insiden Keselamatan Pasien. PERSI. Jakarta.

National Patient Safety Agency. 2008. National Reporting and Learning System; Putting Patient Safety Frst. (Dapat diakses www.npsa.nhs.uk/).

Pinzon, R. 2007. Peran Teknologi Informasi Untuk Meningkatkan Keamanan Pengobatan di Rumah Sakit. Dapat diakses di http://digilib.unsri.ac.id.

Prakoso, AB. 2018. Analisis Kepatuhan Pengisian Surgical Safety Checklist Pada Fase Sign In, Time Out Dan Sign Out Dalam Meningkatkan Patient Safety Di Rumah Sakit Nur Rohmah Gunugkidul. Program Studi Manajemen Rumah Sakit, Universitas Muhammadiyah. Dapat diakses di http://repository.umy.ac.id/handle/123456789/221 $\underline{96}$.

Ridho K.M., Rosa E.M., Suparniati E. 2013. Analisis Faktor-Faktor Yang Mempengaruhi Kepatuhan Pengisian Rekam Medis Di Rumah Sakit Gigi Dan Mulut Pendidikan UMY. Program Studi Manajemen Rumah Sakit, Universitas Muhammadiyah Yogyakarta

Sutoto et al., 2012. Instrumen Akreditasi Rumah Sakit Standar Akreditasi. Versi 2012 1st ed., Jakarta.

Vogts N., Hannam J.A., Merry A.F., Mitchell S.J. 2011. Compliance and quality in administration of a Surgical Safety Checklist in a tertiary New 
Annisa Firdausi et al, Pengaruh Akreditasi Rumah Sakit dalam Perubahan Tingkat Kepatuhan Pengisian Surgical Safety Checklist di RS Nur Hidayah

Zealand hospital. N Z Med J. 2011 Sep 9;124(1342):48-58

Wangoo L., Ray R.A., Ho Y.H. 2016. Compliance and Surgical Team Perceptions of WHO Surgical Safety Checklist; Systematic Review. Int Surg 2016;101:35-49. DOI: 10.9738/INTSURG-D-1500105.1

World Health Organization. 2008. Safe Surgery Saves Lives. World Health Organization. 